\title{
Erratum to: Alectinib: A Review of Its Use in Advanced ALK-Rearranged Non-Small Cell Lung Cancer
}

\author{
Kate McKeage
}

Published online: 14 January 2015

(c) Springer International Publishing Switzerland 2015

\section{Erratum to: Drugs (2015) 75:75-82 \\ DOI 10.1007/s40265-014-0329-y}

The author has alerted us to the following errors:

Page 79, column 2, paragraph 1, line 7.

The sentence that previously read:

'A more recent review of this patient group (median follow-up 141 days) reported that 13 patients, four with prior brain irradiation, continued on study treatment without progression (reported in an abstract) [23].'

should read:

'A more recent review of this patient group (median follow-up 141 days) reported that 13 patients, four without prior brain irradiation, continued on study treatment without progression (reported in an abstract) [23].'
Page 80, figure 4 legend, lines 5 and 6.

The figure legend that previously read:

'Treatment-related adverse events associated with twicedaily alectinib $300 \mathrm{mg}$ in patients with ALK-rearranged advanced non-small cell lung cancer. Adverse events reported in $\geq 10 \%$ of patients $(n=46)$ in the phase 2 portion of a phase 1-2 study [18]. ALP alanine phosphatase, $A L T$ alanine aminotransferase, $A S T$ aspartate aminotransferase, $C P K$ creatinine phosphokinase.'

should read:

'Treatment-related adverse events associated with twicedaily alectinib $300 \mathrm{mg}$ in patients with ALK-rearranged advanced non-small cell lung cancer. Adverse events reported in $\geq 10 \%$ of patients $(n=46)$ in the phase 2 portion of a phase 1-2 study [18]. ALP alkaline phosphatase, $A L T$ alanine aminotransferase, $A S T$ aspartate aminotransferase, $C P K$ creatine phosphokinase.'

The online version of the original article can be found under doi:10.1007/s40265-014-0329-y.

K. McKeage $(\varangle)$

Springer, Private Bag 65901, Mairangi Bay 0754, Auckland, New Zealand

e-mail: demail@springer.com 